\title{
Waste Reduction for Assembly Line Layout with Integration of Lean Tool: Kanban
}

\author{
A.D. Awasare ${ }^{1}$, D.S. Chinchkar ${ }^{2}$, R.N. Panchal ${ }^{3}$, P.R. Pawar $^{4}$ \\ Assistant Professor, Mechanical Engg. Dept, AGTI's DACOE Karad, India ${ }^{1,2}$ \\ Associate Professor, Mechanical Engg. Dept, AGTI's DACOE Karad, India ${ }^{3}$ \\ Assistant Professor, Mechanical Engg. Dept, Bharati Vidyapeeth Navi Mumbai, India ${ }^{4}$
}

\begin{abstract}
Assembly line development and line balancing it is seen that there is some scope for research work in this area. It is proposed to carry out some theoretical and experimental studies on assembly line development and line balancing. Its need to providing comfort and improved working conditions so as to channelize the energy, skills of the workers into constructive productive work.Moving parts from one end of the facility to another end does not add value to the product. Thus, it is important to decrease transportation times within the manufacturing process.The elimination of waste by using lean tool is an essential ingredient for survival in today's manufacturing world. Likewise, works-inprogress should be stored as close as physically possible to the place where they will next be used.
\end{abstract}

Keywords: Assembly Line, Line Balancing, Lean Tool.

\section{INTRODUCTION}

Lean manufacturing is one of the initiatives that many major manufacturing plants in Asia, especially in Malaysia have been trying to adopt in order to remain competitive in an increasingly competitive global market. The focus of the approach is on cost reduction through eliminating non value added activities via applying a management philosophy which focused on identifying and eliminating waste from each step in the production chain respective of energy, time, motion and resources alike throughout a product's value stream, known as lean. Since the birth of Toyota Production System, many of the tools and techniques of lean manufacturing (e.g., just-in-time (JIT), cellular manufacturing, total productive maintenance, single-minute exchange of dies, production smoothing) have been extensively used. This activity is more towards to Toyota Production System (TPS), a systematic approach to identify and eliminate waste activities through continuous improvement. All these effort is objectively to keep cost down and stay ahead in the race. Lean Manufacturing, also called Lean Production, is a set of tools and methodologies that aims for the continuous elimination of all waste in the production process.

The main benefits of this are lower production costs; increased output and shorter production lead times. More specifically, some of the goals include:

1. Defects and wastage - Reduce defects and unnecessary physical wastage, including excess use of raw material inputs, preventable defects, and costs associated with reprocessing defective items and unnecessary product characteristics which are not required by customers.

2. Cycle Times - Reduce manufacturing lead times and production cycle times by reducing waiting times between processing stages, as well as process preparation times and product conversion times.

3. Inventory levels - Minimize inventory levels at all stages of production, particularly works-in-progress between production stages. Lower inventories also mean lower working capital requirements.

4. Labour productivity - Improve labour productivity, both by reducing the idle time of workers and ensuring that when workers are working, they are using their effort as productively as possible.

5. Utilization of equipment and space - Use equipment and manufacturing space more efficiently by eliminating bottlenecks and maximizing the rate of production though existing equipment, while minimizing machine downtime.

6. Flexibility - Have the ability to produce a more flexible range of products with minimum changeover costs and changeover time.

7. Output - Insofar as reduced cycle times, increased labour productivity and elimination of bottlenecks and machine downtime can be achieved.

\section{LEAN PRINCIPAL}

1. Elimination of Waste: eliminate any activities that do not add value in an organization it include overproduction, waiting time, processing, inventory, and motion.

2. Increased Speed and Response: better process designs allow efficient responses to customers' needs and the competitive environment.

3. Improved Quality: Poor quality creates waste, so improving quality is essential to the lean environment. 
IARJSET

International Advanced Research Journal in Science, Engineering and Technology

National Conference on Design, Manufacturing, Energy \& Thermal Engineering (NCDMETE-2017)

AGTI's Dr. Daulatrao Aher College Engineering, Vidyanagar Extension, Karad

Vol. 4, Special Issue 1, January 2017

4. Reduced Cost: simplifying processes and improving efficiency translates to reduced costs.

5. Overproduction- Producing too much or too soon, resulting in poor flow of information or goods and excess inventory.

6. Defects- Frequent errors in paperwork or material/ product quality problems resulting in scrap and rework, as well as poor delivery performance.

7. Unnecessary inventory- Excessive storage and delay of information or products, resulting in excess inventory and costs, leading to poor customer service. Inappropriate processing-Going about work processes using the wrong set of tools, procedures or systems, often when a simpler approach may be more effective.

8. Excessive transportation- Excessive movement of people, information or goods, resulting in wasted time and cost.

9. Zero Inventories: Inventories, including work-inprogress, finished goods and subassemblies, have to be reduced to zero. There will be no more sub-assemblies, no work-in progress and no finished goods.

10. Zero Handling: Zero handling in JIT means eliminating all non-value adding activities

\section{LEAN LAYOUT: KANBAN}

Kanban is an information system that is used to control the number of parts to be produced in every process. The most common types of Kanban are the withdrawal Kanban, which specify the quantity that the succeeding process should pull from the preceding process, and the production Kanban, which specifies the quantity to be produced by the proceeding process. A supplier Kanban is another type of Kanban that is used between the supplier and the manufacturer under JIT.

In order to achieve JIT delivery, suppliers have to adjust from the traditional run sizes to smaller lot sizes. The supplier Kanban circulates between the manufacturer and the supplier. By utilizing a Kanban system under JIT, smaller lot sizes and huge inventory reductions can be achieved. Under this production system raw material, subassemblies and finished product inventory are kept to a minimum and the JIT production principles are followed to eliminate inventory as a source of waste.

A working of kanban system as shown in fig.1.2 the working system is as follow: Assume that the container is moved one at a time. When the containers of the parts is emptied at worker centre $\mathrm{B}$, the empty container and the withdrawal card are taken back to work centre A. The production card is then placed in the kanban receiving post at work centre $\mathrm{A}$, there by authorising production of another container of parts .The empty container is left at work centre A. The full container and withdrawal card are moved to work centre B and placed in the input area. When this container of parts is used, its withdrawal card is empty container are taken back to work centre.

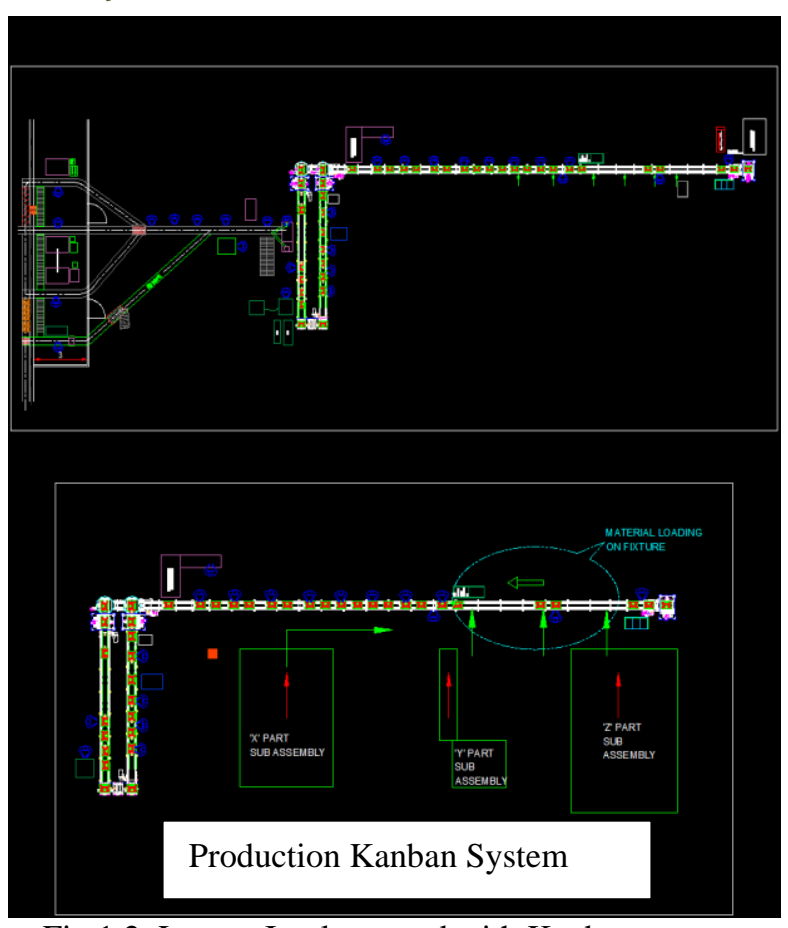

Fig.1.2. Layout Implemented with Kanban system

\section{ANALYSIS OF LEAN LAYOUT: KANBAN}

Method 1:

- Determine time frequency (e.g. every week) and agreed upon size of order to be shipped:

- Determine Takt time for period between agreed upon shipments. (Number of parts to be shipped / time between shipments)

$\mathrm{K}=\mathrm{Tt}=\frac{\mathrm{tS}}{\mathrm{nP}}$

$\mathrm{K}=\mathrm{Tt}=\frac{1.65 * 3600}{264}$

$\mathrm{K}=\mathrm{Tt}=22.5$ No./sec

(Consider Time in sec)

- Kanban size then equals standard order size.

$\mathrm{Tt}=$ Takt Time

$\mathrm{nP}=$ Average number of Parts shipped

$\mathrm{tS}=$ Average time between Shipments

Method 2:

When an assembly is unwilling to utilize a pull system with kanban, then one can set up one's own internal kanban system. The formula for that would be:

$$
\begin{aligned}
& \mathrm{K}=\frac{\mathrm{DL}+\mathrm{SS}}{\mathrm{CS}} \\
& \mathrm{K}=\frac{775+350}{50 * 32 * 14}
\end{aligned}
$$

(Consider Size for One Container)

$\mathrm{K}=0.050 \mathrm{~cm}$ 
IARJSET

International Advanced Research Journal in Science, Engineering and Technology

National Conference on Design, Manufacturing, Energy \& Thermal Engineering (NCDMETE-2017)

AGTI's Dr. Daulatrao Aher College Engineering, Vidyanagar Extension, Karad

Vol. 4, Special Issue 1, January 2017

$\mathrm{K}=$ Kanban size

$\mathrm{DL}=$ Average Demand during Lead time

SS $=$ Safety Stock

$\mathrm{CS}=$ Container Size

Product with Variable Order Size:

- Determine time frequency for shipments and agreed upon normal size (might or might be greater than average size order) order to be shipped.

- Determine highest level of demand for order and frequency demand is greater than agreed upon normal size.

- Determine Takt time for meeting that highest level of demand using standard lead time.

$\mathrm{Tt}=\frac{\mathrm{nP}}{\mathrm{SLt}}$

$22.93=\frac{900}{\mathrm{SLt}}$

$\mathrm{SLt}=39.24 \mathrm{Sec}$

(Consider Time in 'sec')

$\mathrm{Tt}=$ Takt time

$\mathrm{nP}=$ Number of Parts that can be made

$\mathrm{SLt}=$ Standard Lead time
Determine if Takt time can be reached using existing resources. If not, determine amount of lead time needed to be able to meet highest level of demand.

Remark:- 39.24 Sec amount of lead time needed to be able to meet highest level of demand.

\section{RESULT AND DISSCUSSION}

In case of old assembly line material was loaded on fixture at each assembly station as fixture moves from one station to another. While in case of present assembly line material is loaded on the fixture at starting of assembly line \& further material is taken from fixture at each work station for assembly. Due to this modification space required for storage is reduces, mishandling of component, parts is reduces, material flow becomes smooth and well. The new assembly line also shows that subassembly are close to main line terms as $\mathrm{X}$ part assembly, $\mathrm{Y}$ part assembly and $\mathrm{Z}$ Part assembly, so found that part handling movement is less. The following result made by using time study method.

Table I. Comparison result of layout

\begin{tabular}{|c|c|c|c|}
\hline \multirow{2}{*}{ Sr. No. } & \multicolumn{2}{|l|}{ Description } & \multicolumn{2}{l|}{ Assembly Line Layout } \\
\cline { 3 - 4 } & & Previous & \multicolumn{1}{l|}{ Kanban } \\
\hline 1 & Takt time & $22.92 \mathrm{sec}$ & $22.92 \mathrm{sec}$ \\
\hline 2 & Throughput time & $14.87 \mathrm{~min}$ & $10.51 \mathrm{~min}$ \\
\hline 3 & Total idle time of part movement & $58.53 \mathrm{sec}$ & $11.94 \mathrm{sec}$ \\
\hline 4 & Cycle Time & $28.94 \mathrm{sec} / \mathrm{unit}$ & $24.6 \mathrm{sec} / \mathrm{unit}$ \\
\hline 5 & Efficiency & $80.69 \%$ & $92.01 \%$ \\
\hline
\end{tabular}

Table II. Comparison time of Part loading

\begin{tabular}{|l|c|c|}
\hline Part & Previous time in sec & Kanban system time in sec \\
\hline Subassembly X & 67 & 35 \\
\hline Subassembly Y & 52 & 24 \\
\hline Subassembly Z & 34 & 18 \\
\hline Part load No.1 & 14 & 11 \\
\hline Part load No.2 & 12 & 8 \\
\hline Part load No.3 & 13 & 9 \\
\hline Part load No.4 & 13 & 9 \\
\hline Part load No.5 & 9 & 7 \\
\hline Part load No.6 & 7 & 5 \\
\hline
\end{tabular}

\section{CONCLUSION}

The main goal of this paper was to develop the assembly line with lean manufacturing tool kanban system. The first task of this paper was to decide the number of workstations and deciding the layout. For that according to kanban card system new layout is implemented. For previous layout there is production 650 no. of product came out per shift as finished product and for implemented layout production rate is increased by $26.50 \%$. Lean Manufacturing tool is particularly appropriate for any companies that don't have ERP systems.

\section{ACKNOWLEDGEMENT}

We would like to thank the Department of Mechanical Engineering for giving us this valuable and memorable 
experience. We acknowledge with thanks to faculty, teaching and non-teaching staff of the department, Central library and Colleagues. We would like to thank the Emerson Climate Technologies, Atit for their cooperation.

\section{REFERENCES}

1. Babak Javadi \& Alireza Rahimi-Vahed \& Masoud Rabbani \& Mostafa Dangchi, "Solving a multi-objective mixed-model assembly line sequencing problem by a fuzzy goal programming approach", Int J Adv Manuf Technol (2008) 39:975-982 DOI 10.1007/s00170-007-1267-6.

2. Gerald Aase, John R.Olson, Marc J.Schniederjans, "U-shaped assembly line layouts and their impact on labour productivity: An experimental study", European Journal of Operational Research 156 (2004) 698-711.

3. S.J. Hu , J. Ko , L. Weyand, H.A. El Maraghy, T.K. Lien , Y. Koren , H. Bley , G. Chryssolouris f, N. Nasr g, M. Shpitalni, "Assembly system design and operations for product variety", CIRP Annals - Manufacturing Technology 60 (2011) 715-733.

4. Mohammad Kamal Uddin and Jose Luis Martinez Lastra, "Assembly Line Balancing and Sequencing", Tampere University of Technology Finland.

5. Prof M.V.Kavade, Mr. Anant Awasare "A review of assembly line changes for lean manufacturing" at international conference, IOSR Journal of Mechanical and Civil Engineering (IOSR-JMCE) ISSN: 2278-1684, PP: 01-05

6. Prof M.V.Kavade, Mr. Anant Awasare "Compressor assembly line changes for integration with application of lean manufacturing tool", International journal of advanced engineering research and studies-ISSN 0976-3945

7. Mr. Anant Awasare "Reduction of waste by applying lean manufacturing tool for assembly line", International Journal of Engineering Technology, Management and Applied Sciences, February 2016, Volume 4, Issue 2, ISSN 2349-4476 84. 